\title{
PENGARUH PROFITABILITAS, LIKUIDITAS, FIRM SIZE DAN SOLVABILITAS TERHADAP KEBIJAKAN DIVIDEN PADA PERUSAHAAN SEKTOR INDUSTRI BARANG KONSUMSI YANG TERDAFTAR DI BURSA EFEK INDONESIA
}

\author{
Rabi'ah Dea Ihsaniah', Mohamad Adam² Yuliani' ${ }^{3}$ \\ Universitas Sriwijaya Palembang, Sumatera Selatan, Indonesia \\ Email: yulianisyapril@unsri.ac.id
}

\begin{abstract}
Abstrak: Penelitian ini bertujuan untuk menguji pengaruh Profitabilitas (ROA), Likuiditas (CR), Firm Size (FZ)dan Solvabilitas (DER) terhadap Kebijakan Dividen (DPR). Populasi dalam penelitian ini adalah perusahaan sektor Industri Barang Konsumsi yang terdaftar di Bursa Efek Indonesia (BEI) pada periode 2012-2016. Sampel yang dikumpulkan menggunakan metode purposive sampling. Total 13 perusahaan ditentukan sebagai sampel. Metode analisis penelitian ini menggunakan regresi linier berganda. Hasil penelitian ini menunjukkan bahwa Firm Size berpengaruh terhadap kebijakan dividen (DPR). Sementara profitabilitas (ROA), likuiditas (CR) dan solvabilitas (DER) tidak berpengaruh terhadap kebijakan dividen (DPR). Hasil koefisien determinasi menunjukkan sebesar $11,7 \%$. Hal tersebut menandakan kemampuan variabel independen dalam menjelaskan variabel dependen, sementara $88,3 \%$ dijelaskan oleh variabel lain.
\end{abstract}

Kata kunci: profitabilitas (roa); likuiditas (cr); firm size; solvabilitas (der) dan kebijakan dividen

\begin{abstract}
This study aims to examine the effect of Profitability (ROA), Liquidity (CR), Firm Size (FZ) and Solvency (DER) on Dividend Policy (DPR). The population in this study is the consumer goods industry sector companies listed on the Indonesia Stock Exchange (BEI) in the 2012-2016 period. Samples were collected using purposive sampling method. A total of 13 companies were determined as samples. The method of analysis of this research is using multiple linear regression. The results of this study indicate that Firm Size has an effect on dividend policy (DPR). Meanwhile profitability $(R O A)$, liquidity (CR) and solvency (DER) have no effect on dividend policy (DPR). The result of the coefficient of determination is $11.7 \%$. This indicates the ability of the independent variable to explain the dependent variable, while $88.3 \%$ is explained by other variables.
\end{abstract}

Keywords: profitability (roa); liquidity (cr); firm size; solvency (der) and dividend policy 


\section{PENDAHULUAN}

Dividen merupakan pembagian dari keuntungan yang dibagikan kepada pemegang saham yang dapat berupa dividen tunai atau dividen saham (Gumanti, 2013). Dividen merupakan feed back dari perusahaan yang diberikan kepada pemegang saham atau investor. Tujuan utama dari investor dalam menanamkan dananya ke dalam perusahaan adalah untuk mendapatkan tingkat pengembalian baik berupa capital gain maupun dividen. Hal ini berbeda dengan keinginan perusahaan yang lebih menyukai laba ditahan dibandingkan dengan membagi dividen karena laba ditahan tersebut digunakan untuk membiayai kegiatan operasi perusahaan dan meminimumkan pinjaman modal dari pihak luar.

Kebijakan dividen merupakan suatu keputusan pembelanjaan internal perusahaan sehingga besar kecilnya nilai dividen yang dibagikan akan mempengaruhi jumlah laba ditahan (Sudana, 2011). Kebijakan dividen dapat dijadikan salah satu pertimbangan untuk melakukan penanaman dana pada suatu perusahaan. Kebijakan dividen dapat dilihat dari Dividend Payout Ratio (DPR). Dividend Payout Ratio (selanjutnya akan ditulis DPR) merupakan hasil perbandingan antara dividen dengan laba yang dibayarkan kepada pemegang saham berupa dividen kas (Silviana, 2014). Namun terdapat beberapa faktor yang dapat mempengaruhi pembagian dividen, misalnya faktor internal seperti profitabilitas, likuiditas, solvabilitas, ukuran perusahaan dan lainnya.

Menurut (Marietta, 2013), (Hanif \& Bustamam, 2017), (Lioew et al., 2014), (Kartika, 2015), (Janifairus et al., 2013), (Afrina, 2014), (Ano et al., 2014), (Usman \& Mustafa, 2016) menyatakan bahwa ROA berpengaruh positif dan signifikan terhadap DPR baik secara parsial maupun simultan. Hal ini tidak sejalan dengan hasil penelitian dari (Ritha \& Koestiyanto, 2013), (Swastyastu et al., 2014), (Deni et al., 2016) yang menyatakan bahwa ROA tidak berpengaruh terhadap DPR baik secara parsial maupun simultan.

Menurut (Afrina, 2014) mengungkapkan bahwa Current Ratio (CR) secara simultan berpengaruh terhadap DPR. Menurut (Ano et al., 2014) secara simultan berpengaruh terhadap DPR dan CR secara parsial juga berpengaruh signifikan terhadap DPR. Hal ini tidak sama dengan hasil penelitian dari (Astiti et al., 2017) bahwa CR berpengaruh negatif terhadap DPR secara parsial.

Menurut (Marietta, 2013) menyatakan bahwa Firm Size berpengaruh positif dan signifikan terhadap DPR sedangkan menurut (Astiti et al., 2017) Firm Size berpengaruh tidak signifikan terhadap DPR, (Pribadi, 2012) menyatakan bahwa Firm Size berpengaruh negatif dan signifikan terhadap DPR. (Deni et al., 2016) menyatakan bahwa Firm Size secara parsial berpengaruh positif tidak signfikan terhadap DPR. Hal ini tidak sejalan dengan (Ritha \& Koestiyanto, 2013), (Swastyastu et al., 2014) yang menyatakan bahwa Firm Size tidak berpengaruh signifikan terhadap DPR. 
Menurut (Marietta, 2013), (Usman \& Mustafa, 2016) menyatakan bahwa Debt to Equity Ratio (DER) berpengaruh positif dan signifikan terhadap DPR. Lalu, (Janifairus et al., 2013) menyatakan bahwa DER secara parsial tidak berpengaruh terhadap DPR. Sedangkan menurut (Astiti et al., 2017), (Hanif \& Bustamam, 2017), (Swastyastu et al., 2014), (Pribadi, 2012) menyatakan bahwa DER tidak berpengaruh terhadap DPR.

Perusahaan sektor industri barang konsumsi memiliki saham yang aktif diperdagangkan di bursa saham sehingga harga sahamnya juga bergerak aktif. Selain itu, terjaganya pertumbuhan sektor barang konsumsi mendapatkan apresiasi yang positif dari investor dan masyarakat juga lebih mengenal emiten-emiten di industri barang konsumsi karena produk yang ditawarkan merupakan bahan kebutuhan sehari-hari masyarakat.

Berdasarkan data laporan keuangan perusahaan sektor industri konsumi Go Public periode 2012-2016 mengenai nilai Dividend Payout Ratio (DPR), diuraikan sebagai berikut:

Tabel 1

Data Dividend Payout Ratio (DPR) Perusahaan Sektor Industri Barang Konsumsi yang Menjadi Sampel Penelitian

\begin{tabular}{lccccc}
\hline & \multicolumn{5}{c}{ Tahun } \\
\cline { 2 - 6 } \multicolumn{1}{c}{ Kode } & $\mathbf{2 0 1 2}$ & $\mathbf{2 0 1 3}$ & $\mathbf{2 0 1 4}$ & $\mathbf{2 0 1 5}$ & $\mathbf{2 0 1 6}$ \\
\hline DLTA & 86,29 & 72,66 & 68,09 & 50,44 & 59,02 \\
\hline ICBP & 49,75 & 49,79 & 49,71 & 49,75 & 56,41 \\
\hline INDF & 49,82 & 49,81 & 49,72 & 49,71 & 45,52 \\
\hline MYOR & 23,68 & 19,75 & 30,96 & 21,99 & 39,81 \\
\hline GGRM & 38,35 & 35,56 & 28,67 & 57,73 & 63,71 \\
\hline HMSP & 57,29 & 80,71 & 86,45 & 89,89 & 55,22 \\
\hline DVLA & 39,49 & 32,72 & 32,44 & 52,47 & 30,53 \\
\hline KAEF & 15,29 & 25,00 & 20,00 & 19,55 & 26,66 \\
\hline KLBF & 66,77 & 44,97 & 43,14 & 44,44 & 52,31 \\
\hline MERK & 30,71 & 38,82 & 62,23 & 53,43 & 35,71 \\
\hline TSPC & 53,13 & 53,18 & 58,25 & 43,11 & 49,05 \\
\hline TCID & 49,47 & 46,45 & 44,99 & 15,14 & 57,13 \\
\hline UNVR & 80,96 & 78,93 & 48,67 & 73,88 & 44,77 \\
\hline
\end{tabular}

Sumber: Laporan keuangan perusahaan, diolah (2017)

Berdasarkan Tabel 1 di atas dapat dilihat bahwa selalu terjadi lonjakan maupun penurunan yang cukup besar dan signifikan pada perusahaan sektor industri barang konsumsi pada tahun 2012-2016 yang mana fenomena ini menarik untuk diteliti lebih lanjut bahwa faktor-faktor apa saja yang telah menyebabkan DPR tiap perusahaan berfluktuasi. Lalu, berdasarkan uraian latar belakang, fenomena gap dan reserach gap dari penelitian terdahulu mengenai hubungan Return On Asset (ROA), Current Ratio (CR), Firm Size dan Debt to Equity Ratio (DER) terhadap Dividend 
Payout Ratio (DPR), maka peneliti berminat untuk melakukan penelitian yang berjudul: "Pengaruh Profitabilitas, Likuiditas, Firm Size dan SolvabilitasTerhadap Kebijakan Dividen pada Perusahaan Sektor Industri Barang Konsumi yang Terdaftar di Bursa Efek Indonesia"

\section{METODE PENELITIAN}

\section{Ruang Lingkup dan Objek Penelitian}

Batasan ruang lingkup dalam penelitian ini adalah pengaruh Return On Asset (ROA), Current Ratio (CR), Firm Size dan Debt to Equity Ratio (DER) terhadap Dividend Payout Ratio (DPR) pada perusahaan sektor industri barang konsumsi yang terdaftar di Bursa Efek Indonesia periode 2012-2016.

\section{Jenis dan Sumber Data}

Jenis data dalam penelitian merupakan data kuantitatif yaitu data yang dinyatakan dalam bentuk angka. Sumber data yang digunakan merupakan data sekunder, yaitu laporan keuangan dari perusahaan sektor industri barang konsumsi yang terdaftar di Bursa Efek Indonesia periode 2012-2016. Data penelitian ini diperoleh dari internet (www.idx.co.id).

\section{Populasi dan Sampel}

\section{a. Populasi}

Populasi dalam penelitian ini merupakan seluruh perusahaan sektor industri barang konsumsi yang terdaftar di Bursa Efek Indonesia yang berjumlah 40 perusahaan.

b. Sampel

Pemilihan sampel dilakukan berdasarkan metode purposive sampling. Berdasarkan40 populasi perusahaan sektor industri konsumsi yang terdaftar di Bursa Efek Indonesia diperoleh sampel sebanyak 13 perusahaan yang sesuai dengan kriteria yang telah ditetapkan.

\section{Metode Analisis Data}

a. Statistik Deskriptif

Statisktik deskriptif adalah statistik yang digunakan untuk menganalisis data dengan cara mendeskripsikan atau menggambarkan data yang telah terkumpul sebagaimana adanya tanpa bermaksud membuat kesimpulan yang berlaku untuk umum atau generalisasi (Sanusi, 2016).

\section{b. Analisis Regresi Linier Berganda}

Merupakan analisis hubungan linier antara dua atau lebih variabel independen dengan variabel dependen. Analisis ini digunakan untuk mengetahui arah hubungan antar variabel independen dan dependen dan digunakan untuk memprediksi nilai 
variabel dependen jika terjadi kenaikan atau penurunan pada nilai variabel independen (Sanusi, 2016).

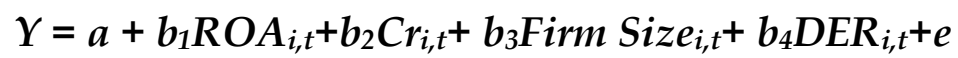

\section{Uji Normalitas}

Uji Normalitas dilakukan untuk menguji dan meilhat apakah pada model regresi, variabel pengganggu atau residual terdistribusi secara normal.Seperti diketahui bahwa uji $\mathrm{F}$ dan $\mathrm{t}$ mengasumsikan bahwa nilai residual mengikuti distribusi normal, jika asumsi ini dilanggar atau tidak sesuai maka uji statistik menjadi tidak valid untuk jumlah sampel kecil (Ghozali, 2011).

\section{Uji Asumsi Klasik}

\section{a. Uji Multikolinearitas}

Uji multikolinearitas dilakukan untuk menguji apakah terdapat korelasi antar variabel bebas (independen) atau tidak dalam model regresi. Menurut (Sanusi, 2016) pendekatan terhadap multikolinearitas dapat dilakukan dengan melihat Variance Inflating Factor (VIF) dan nilai Tolerance.

\section{b. Uji Autokorelasi}

Uji Autokorelasi bertujuan untuk menguji apakah terdapat korelasi antara kesalahan pengganggu pada periode $t$ dengan $t-1$ (Ghozali, 2011).Uji yang dapat digunakan untuk mengetahui terjadi autokorelasi atau tidak dalam suatu model regresi digunakan dengan melihat nilai dari statistik Durbin-Watson (Sanusi, 2016).

\section{c. Uji Heterokedastisitas}

Uji Heteroskedastisitas bertujuan untuk menguji apakah varian residual regresi dari satu pengamatan ke pengamatan lain sama atau berbeda. Nilai yang tidak sama antar satu varians dari residual ditunjukkan dengan pola yang tidak sama. Jika varian dari residual satu pengamatan ke pengamatan lain tetap, maka disebut homoskedastisitas dan jika varians dari residual satu pengamatan ke pengamatan lain berbeda disebut heterokedastisitas. Model regresi yang baik adalah yang terjadi homokedastisitas atau tidak terjadi heteroskedastisitas (Ghozali, 2011). 


\section{HASIL PENELITIAN DAN PEMBAHASAN}

\section{A. Hasil Penelitian}

\section{Hasil Uji Statistik Deskriptif}

Hasil penelitian ndepende deskriptif variabel-variabel yang digunakan dalam penelitian ini adalah sebagai berikut:

Tabel 1

Uji Statistik Deskriptif

Descriptive Statistics

\begin{tabular}{cccccc}
\hline & N & $\begin{array}{c}\text { Minimu } \\
\text { m }\end{array}$ & Maximum & Mean & $\begin{array}{c}\text { Std. } \\
\text { Deviation }\end{array}$ \\
\hline ROA & 65 & 1,97 & 41,55 & 13,1485 & 8,48723 \\
\hline CR & 65 & 48,16 & 757,27 & 185,4471 & 130,97429 \\
\hline SIZE & 65 & 12,14 & 30,35 & 17,1531 & 4,07920 \\
\hline DER & 65 & 0,09 & 3,67 & 1,3551 & 1,19930 \\
\hline DPR & 65 & 15,14 & 89,89 & 48,1546 & 17,81876 \\
\hline & Sumber: Data Sekunder diolah, 2017 &
\end{tabular}

Berdasarkan Tabel Statistik Deskriptif 1 dapat dilihat bahwa jumlah data $(\mathrm{N})$ dalam penelitian ini adalah 65. Variabel ndependent pada penelitian ini adalah Return On Assets (ROA), Current Ratio (CR), Firm Size dan Debt to Equity Ratio (DER). Hasil diperoleh hasil sebagai berikut:

1. Variabel Return On Assets (ROA) menunjukkan nilai minimum sebesar 1,97, nilai maksimum sebesar 41,55, nilai rata-rata sebesar 13,1485 dan standar deviasi sebesar 8,48723. Semakin kecil standar deviasi yang dimiliki perusahaan sektor industri barang konsumsi artinya semakin rendah penyebaran data pengamatan dan memiliki variabilitas rendah. Variabel Current Ratio (CR) menunjukkan nilai minimum 48,16, nilai maksimum 757,27, nilai rata-rata 185,4471 dan standar deviasi sebesar 103,97429. Semakin besar standar deviasi yang dimiliki perusahaan sektor industri barang konsumsi artinya semakin menyebar data pengamatan dan memiliki kecenderungan setiap data berbeda atau memiliki variabilitas tinggi.

2. Variabel Firm Size menunjukkan nilai minimum sebesar 12,14, nilai maksimum sebesar 30,35, nilai rata-rata sebesar 17,1531 dan standar deviasi sebesar 4,07920. Semakin kecil standar deviasi yang dimiliki perusahaan sektor industri barang konsumsi artinya semakin rendah penyebaran data pengamatan dan memiliki variabilitas rendah.

3. Variabel Debt to Equity Ratio (DER) menunjukkan nilai minimum sebesar 0,09, nilai maksimum sebesar 3,67, nilai rata-rata sebesar 1,3551 dan standar deviasi sebesar 1,19930. Semakin kecil standar deviasi yang dimiliki perusahaan sektor industri barang 
konsumsi artinya semakin rendah penyebaran data pengamatan dan memiliki variabilitas rendah.

4. Variabel Dividend Payout Ratio (DPR) menunjukkan nilai minimum sebesar 15,14 , nilai maksimum sebesar 89,96 , nilai ratarata sebesar 48,1546 dan standar deviasi sebesar 17,81876. Semakin besar standar deviasi yang dimiliki perusahaan sektor industri barang konsumsi artinya semakin menyebar data pengamatan dan memiliki kecenderungan setiap data berbeda atau memiliki variabilitas tinggi.

\section{Hasil Uji Normalitas}

Penelitian ini menggunakan taraf signifikansi 5\%, dengan melihat nilai signifikansi dari nilai Kolmogorov Smirnov $>\mathrm{a}(\mathrm{sig}>\mathrm{a}=$ 0,05), maka data yang digunakan berdistribusi normal (Ghozali, 2011: 160). Adapun hasil uji normalitas adalah sebagai berikut:

Tabel 2

Hasil Uji Normalitas (sebelum transformasi data) One-Sample Kolmogorov-Smirnov Test

\begin{tabular}{llccccc}
\hline & & ROA & CR & SIZE & DER & DPR \\
\hline $\mathrm{N}$ & & 65 & 65 & 65 & 65 & 65 \\
\hline $\begin{array}{l}\text { Normal } \\
\text { Parameters }\end{array}$ & Mean & 13,1485 & 185,4471 & 17,1531 & 1,3551 & 48,1546 \\
\cline { 2 - 7 } & $\begin{array}{l}\text { Std. } \\
\text { Deviation }\end{array}$ & 8,48723 & $\begin{array}{c}130,9742 \\
9\end{array}$ & 4,07920 & 1,19930 & $\begin{array}{c}17,8187 \\
6\end{array}$ \\
\hline $\begin{array}{l}\text { Most Extreme } \\
\text { Differences }\end{array}$ & Absolute & 0,097 & 0,191 & 0,217 & 0,191 & 0,091 \\
\cline { 2 - 7 } & Positive & 0,097 & 0,191 & 0,217 & 0,191 & 0,091 \\
\cline { 2 - 7 } & Negative & $-0,094$ & $-0,156$ & $-0,154$ & $-0,146$ & $-0,065$ \\
\hline Test Statistic & & 0,097 & 0,191 & 0,217 & 0,191 & 0,091 \\
\hline Asymp. Sig. (2-tailed) & 0,200 & 0,000 & 0,000 & 0,000 & 0,200 \\
\hline
\end{tabular}

Berdasarkan hasil uji normalitas One-Sample KalmogorovSmirnov pada Tabel 2 di atas dapat dilihat bahwa hanya Return On Assets (ROA) dan Dividend Payout Ratio (DPR) yang terdistribusi secara normal dikarenakan Asymp. Sig (2-tailed) berada diatas 5\% (sig $>a=0,05)$. Sedangkan variabel Current Ratio (CR), Firm Size, Debt to Equity Ratio (DER) tidak terdistribusi secara normal karena Asymp. Sig (2-tailed) dibawah 5\%. Hal tersebut menunjukkan bahwa terdapat data residual yang terdistribusi tidak normal. Untuk mengubah nilai residual agar berdistribusi normal, penulis melakukan transformasi data yaitu dengan melakukan boxplot atau membuang data outlier. Adapun data outlier tersebut adalah sebagai berikut: 
Tabel 3

Data Outlier yang Dihapus

\begin{tabular}{cc}
\hline Variabel & Data Outlier \\
\hline CR & $65,50,49,43$ \\
\hline SIZE & $60,55,45,40,20$ \\
\hline DER & $4,3,2,1$ \\
\hline
\end{tabular}

Sumber: Data Sekunder diolah, 2017

Tabel 4

Hasil Uji Normalitas (setelah transformasi data) One-Sample Kolmogorov-Smirnov Test

\begin{tabular}{llccccc}
\hline & \multicolumn{1}{c}{ ROA } & $\mathbf{C R}$ & SIZE & DER & DPR \\
\hline $\mathbf{N}$ & & $\mathbf{5 2}$ & $\mathbf{5 2}$ & $\mathbf{5 2}$ & $\mathbf{5 2}$ & $\mathbf{5 2}$ \\
\hline $\begin{array}{l}\text { Normal } \\
\text { Parameters }\end{array}$ & Mean & 12,4775 & 163,9915 & 16,2646 & 1,1254 & 47,1262 \\
\cline { 2 - 7 } & $\begin{array}{l}\text { Std. } \\
\text { Deviation }\end{array}$ & 8,55734 & 89,67783 & 1,89574 & 0,66770 & 18,23511 \\
\hline $\begin{array}{l}\text { Most Extreme } \\
\text { Differences }\end{array}$ & Absolute & 0,110 & 0,151 & 0,069 & 0,097 & 0,095 \\
\cline { 2 - 7 } & Positive & 0,102 & 0,151 & 0,069 & 0,097 & 0,095 \\
\cline { 2 - 7 } & Negative & $-0,110$ & $-0,107$ & $-0,061$ & $-0,069$ & $-0,076$ \\
\hline Test Statistic & & 0,110 & 0,151 & 0,069 & 0,097 & 0,095 \\
\hline \multicolumn{2}{l}{ Asymp. Sig. (2-tailed) } & 0,168 & 0,005 & 0,200 & 0,200 & 0,200 \\
\hline
\end{tabular}

Sumber: Data Sekunder diolah, 2017

Berdasarkan hasil uji normalitas One-Sample Kalmogorov-Smirnov pada Tabel 4 di atas dapat dilihat bahwa hanya Return On Assets (ROA), Firm Size, Debt to Equity Ratio (DER) dan Dividend Payout Ratio (DPR) yang terdistribusi secara normal dikarenakan Asymp. Sig (2-tailed) berada diatas 5\%. Sedangkan variabel Current Ratio (CR) tidak terdistribusi secara normal karena Asymp. Sig (2-tailed) dibawah 5\%. Hal tersebut menunjukkan bahwa terdapat data residual yang terdistribusi tidak normal. Untuk mengubah nilai residual agar berdistribusi normal, penulis melakukan transformasi data yaitu dengan melakukan Ln pada variabel. Current Ratio (CR) sehingga didapatkan hasil sebagai berikut:

Tabel 5

Hasil Uji Normalitas (setelah transformasi data)

\begin{tabular}{llccccc}
\hline \multicolumn{7}{c}{ One-Sample Kolmogorov-Smirnov Test } \\
\hline $\mathbf{N}$ & \multicolumn{7}{c}{ ROA } & LN_CR & SIZE & DER & DPR \\
\hline \multirow{2}{*}{ Normal Parameters } & Mean & $\mathbf{5 2}$ & $\mathbf{5 2}$ & $\mathbf{5 2}$ & $\mathbf{5 2}$ & $\mathbf{5 2}$ \\
\cline { 2 - 7 } & $\begin{array}{l}\text { Std. } \\
\text { Deviation }\end{array}$ & 8,55734 & 0,9652 & 16,2646 & 1,1254 & 47,1262 \\
\hline \multirow{2}{*}{$\begin{array}{l}\text { Most Extreme } \\
\text { Differences }\end{array}$} & Absolute & 0,110 & 0,086 & 0,069 & 0,097 & 0,095 \\
\cline { 2 - 7 } & Positive & 0,102 & 0,076 & 0,069 & 0,097 & 0,095 \\
\cline { 2 - 7 } & Negative & $-0,110$ & $-0,086$ & $-0,061$ & $-0,069$ & $-0,076$ \\
\hline Test Statistic & & 0,110 & 0,086 & 0,069 & 0,097 & 0,095 \\
\hline Asymp. Sig. (2-tailed) & & 0,168 & 0,200 & 0,200 & 0,200 & 0,200 \\
\hline
\end{tabular}

Sumber: Data Sekunder diolah, 2017 
Berdasarkan hasil uji pada Tabel 5 maka dapat ditarik kesimpulan bahwa variabel terdistribusi secara normal dan memenuhi asumsi klasik persyaratan yang dinyatakan normal bila probability lebih besar dari tingkat signifikansi (sig $>a=0,05)$ dapat dikatakan bahwa data menyebar dengan normal (Supriyadi, 2014)

\section{Hasil Uji Asumsi Klasik}

a. Hasil Uji Multikolinearitas

Menurut (Sanusi, 2016) pendekatan terhadap multikolinearitas dapat dilakukan dengan melihat Variance Inflating Factor (VIF) dan nilai Tolerance. Nilai untuk tolerance mempunyai angka mendekati angka 1 dan nilai untuk VIF adalah lebih kecil daripada 10, berarti variabel independen tidak mengalami korelasi. Berikut tabel yang menunjukkan nilai tolerance dan VIF:

Tabel 6

Hasil Uji Multikolinearitas Coefficients ${ }^{a}$

\begin{tabular}{lcc}
\hline & \multicolumn{2}{c}{ Collinearity Statistics } \\
\cline { 2 - 3 } \multicolumn{1}{c}{ Model } & Tolerance & VIF \\
\hline ROA & 0,975 & 1,025 \\
\hline LN_CR & 0,595 & 1,680 \\
\hline SIZE & 0,861 & 1,161 \\
\hline DER & 0,571 & 1,751 \\
\hline
\end{tabular}

Berdasarkan hasil output uji multikolinearitas pada Tabel 6 di atas, dapat dilihat jika masing-masing nilai dari Tolerance dari masing masing variabel independen yaitu Return on Assets (ROA) sebesar 0,975\%, Current Ratio (CR) sebesar 0,595\%, Firm Size sebesar 0,861\% dan Debtto Equity (DER) sebesar 0,571\%. Keempat variabeltersebut memiliki nilai Tolerance yang lebih besar dari 0,10 maka dapat disimpulkan bahwa tidak terjadi multikolinearitas pada data yang diuji. Nilai VIF dari masingmasing variabel independen yaitu Return on Assets (ROA), Current Ratio (CR), Firm Size dan Debt to Equity (DER) berdasarkan Tabel 4.3 di atas nilai Return on Assets (ROA) sebesar 1,025\%, Current Ratio (CR) sebesar 1,680\%, Firm Size sebesar 1,161\% dan Debt to Equity (DER) sebesar 1,751\%. Keempat variabel tersebut memiliki nilai VIF yang lebih kecil dari 10,00 maka dapat disimpulkan bahwa pada data yang diuji tidak terjadi multikolinearitas. 


\section{b. Hasil Uji Heterokedastisitas}

Uji Heteroskedastisitas bertujuan untuk menguji apakah varian residual regresi dari satu pengamatan ke pengamatan lain sama atau berbeda. Pola yang tidak sama ditunjukkan dengan nilai yang tidak sama antar satu varians dari residual.

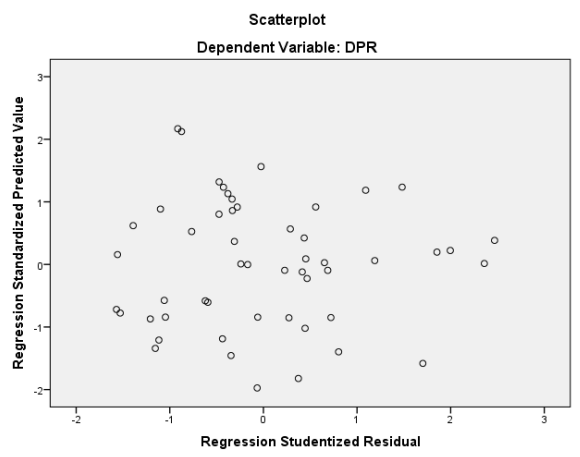

Gambar 1

Uji Heterokedastisitas

Sumber: Data Sekunder diolah, 2017

Berdasarkan Gambar scatterplot 1 dapat dilihat bahwa titiktitik menyebar dan tidak membentuk pola tertentu yang jelas. Titik-titik menyebar di atas dan di bawah angka 0 pada sumbu Y. Dari hasil tersebut maka dapat disimpulkan bahwa persamaan model regresi tidak terdapat masalah heterokedastisitas dan layak untuk digunakan pada analisis selanjutnya.

\section{c. Hasil Uji Autokorelasi}

Uji Autokorelasi bertujuan untuk menguji apakah dalam model regresi linier ada korelasi antara kesalahan pengganggu pada periode $t$ dengan kesalahan pengganggu pada periode $t-1$ (Ghozali, 2011). Berikut ini merupakan hasil uji autokorelasi:

Tabel 7

Hasil Uji Autokorelasi

Model Summary ${ }^{b}$

\begin{tabular}{cc}
\hline Model & Durbin-Watson \\
\hline 1 & 1,084 \\
\hline \multicolumn{2}{c}{ Sumber: } \\
Data Sekunder diolah, 2017
\end{tabular}

Berdasarkan hasil uji autokorelasi pada Tabel 4.6. dapat dilihat bahwa nilai DW 1,084 yang mana berada diantara -2 sampai +2 , maka tidak ada masalah atau tidak ada autokorelasi. Berdasarkan hasil DW tersebut, model regresi tidak terjadi gejala autokorelasi positif dan negatif diantara variabel-variabel 
independen, maka dapat disimpulkan bahwa model regresi ini layak digunakan.

\section{d. Hasil Analisis Regresi Linier Berganda}

Analisis linier berganda adalah hubungan linier antara dua atau lebih variabel independen dengan variabel dependen.

Tabel 8

Hasil Uji Regresi Linier Berganda

Coefficients ${ }^{a}$

\begin{tabular}{|c|c|c|c|}
\hline \multirow{2}{*}{\multicolumn{2}{|c|}{ Model }} & \multicolumn{2}{|c|}{ Unstandardized Coefficients } \\
\hline & & B & Std. Error \\
\hline \multirow[t]{5}{*}{1} & $\begin{array}{l}\text { (Constan } \\
\text { t) }\end{array}$ & $-1,468$ & 41,318 \\
\hline & ROA & $-0,180$ & 0,284 \\
\hline & LN_CR & $-1,916$ & 5,960 \\
\hline & SIZE & 4,161 & 1,364 \\
\hline & $\overline{\text { DER }}$ & $-6,507$ & 4,757 \\
\hline
\end{tabular}

Sumber: Data Sekunder diolah, 2017

Berdasarkan Tabel 8. maka diperoleh persamaan regresi linier berganda sebagai berikut:

\section{DPR $=-1,468-0,180$ ROA - 1,916 CR + 4,161 SIZE - 6,507 DER + e}

Berdasarkan Tabel 8. dapat ditarik kesimpulan bahwa variabel Return On Assets (ROA) tidak berpengaruh terhadap Dividend Payout Ratio (DPR) dilihat dari nilai signifikan sebesar 0,528 lebih besar dari 0,05. Variabel Current Ratio (CR) tidak berpengaruh terhadap Dividend Payout Ratio (DPR) karena jika dilihat dari nilai signifikan sebesar 0,749 yang mana lebih besar dari 0,05. Variabel Firm Size berpengaruh signifikan terhadap Dividend Payout Ratio (DPR) karena dilihat dari nilai signifikan sebesar 0,004 yang mana lebih kecil dari 0,05. Variabel Debt to Equity Ratio (DER) tidak berpengaruh terhadap Dividend Payout Ratio (DPR) karena nilai signifikan sebesar 0,178 yang mana lebih besar dari nilai 0,05 .

\section{e. Hasil Uji Kelayakan Model}

Uji kelayakan model atau uji - F dilakukan untuk mengetahui apakah variabel independen berpengaruh terhadap variabel dependen (Sanusi, 2016). Berdasarkan hasil pengelolaan data diperoleh hasil sebagai berikut: 
Tabel 9

Hasil Uji Kelayakan Model ANOVAa

\begin{tabular}{lllcccc}
\hline & Model & $\begin{array}{c}\text { Sum of } \\
\text { Squares }\end{array}$ & df & $\begin{array}{c}\text { Mean } \\
\text { Square }\end{array}$ & F & Sig. \\
\hline \multirow{2}{*}{1} & Regression & 3152,365 & 4 & 788,091 & 2,683 & 0,043 \\
\cline { 2 - 7 } & Residual & 13806,125 & 47 & 293,747 & & \\
\cline { 2 - 7 } & Total & 16958,489 & 51 & & & \\
\hline \multicolumn{7}{c}{ Sumber: Data Sekunder diolah, 2017 }
\end{tabular}

Berdasarkan Tabel 9 di atas menunjukkan bahwa F-hitung sebesar 2,683 dengan probabilitas tingkat signifikansi 0,043 lebih kecil dari tingkat signifikansi yang diharapkan $(\operatorname{sig}<\alpha=0,05)$. Hal ini menunjukkan bahwa Return On Assets (ROA), Current Ratio (CR), Firm Size dan Debt to Equity Ratio (DER) berpengaruh terhadap variabel dependen Dividend Payout Ratio (DPR) pada perusahaan sektor industri barang konsumsi yang terdaftar di Bursa Efek Indonesia 2012-2016 dan layak untuk digunakan pada analisis selanjutnya.

\section{f. Hasil Uji Koefisien Determinasi $\left(\mathbf{R}^{2}\right)$}

Koefisien determinasi $\left(\mathrm{R}^{2}\right)$ digunakan untuk mengetahui presentase pengaruh variabel independen terhadap variabel dependen (Sanusi, 2016). Berikut adalah tabel hasil uji koefisien determinasi:

Tabel 10

Hasil Uji Koefisien Determinasi

Model Summaryb

\begin{tabular}{ccccc}
\hline Model & R & R Square & $\begin{array}{c}\text { Adjusted R } \\
\text { Square }\end{array}$ & $\begin{array}{c}\text { Std. Error of } \\
\text { the Estimate }\end{array}$ \\
\hline 1 & 0,431 & 0,186 & 0,117 & 17,13906 \\
\hline \multicolumn{4}{c}{ Sumber: Data Sekunder diolah, 2017}
\end{tabular}

Hasil uji koefisien determinasi di atas menunjukkan bahwa nilai $R$ adalah 0,431, $R$ Square 0,186 dan Adjusted $R$ Square 0,117. Kondisi ini menunjukkan bahwa hanya $11,7 \%$ variasi Dividend Payout Ratio (DPR) dipengaruhi oleh Return On Assets (ROA), Current Ratio (CR), Firm Size dan Debt to Equity Ratio (DER). Sedangkan, sisanya $88,3 \%$ dipengaruhi oleh variabel-variabel lain yang tidak diteliti. 


\section{g. Hasil Uji- t (Parsial)}

Uji-t dilakukan untuk mengetahui apakah semua variabel independen secara parsial berpengaruh signifikan terhadap variabel dependen (Sanusi, 2016: 138). Berikut merupakan hasil uji parsial:

Tabel 11

Hasil Uji Parsial

Coefficients $^{a}$

\begin{tabular}{llll}
\hline & & \multicolumn{1}{c}{ Model } & Sig. \\
\hline 1 & (Constant) & $-0,036$ & 0,972 \\
\cline { 2 - 4 } & ROA & $-0,635$ & 0,528 \\
\cline { 2 - 4 } & LN_CR & $-0,322$ & 0,749 \\
\cline { 2 - 4 } & 3,050 & 0,004 \\
\cline { 2 - 3 } & SIZE & $-1,368$ & 0,178 \\
\hline
\end{tabular}

Sumber: Data Sekunder diolah, 2017

Berdasarkan hasil Uji Parsial pada Tabel 11. di atas, maka dapat dijelaskan pengaruh masing-masing variabel independen terhadap variabel dependen sebagai berikut:

1. Variabel Return On Assets (ROA)

Nilai koefisien regresi variabel Return On Assets (ROA) yang diperoleh adalah sebesar $-0,180$, nilai $\mathrm{t}$ hitung sebesar -0,635 dan probabilitas tingkat signifikan sebesar 0,528 lebih besar dari tingkat signifikan $(52,8 \%>\mathrm{a}=0,05)$. Maka $\mathrm{H}_{1}=$ Return On Assets berpengaruh terhadap Dividend Payout Ratio (DPR) ditolak.

2. Variabel Current Ratio (CR)

Nilai koefisien regresi variabel Current Ratio (CR) yang diperoleh adalah sebesar -1,916, nilai $t$ hitung sebesar -1,322 dan probabilitas tingkat signifikan sebesar 0,749 lebih besar dari tingkat signifikan $(74,9 \%>\mathrm{a}=0,05)$. Maka $\mathrm{H}_{2}=$ Current Ratio (CR) berpengaruh terhadap Dividend Payout Ratio (DPR) ditolak.

3. Variabel Firm Size

Nilai koefisien regresi variabel Firm Size yang diperoleh adalah sebesar 4,161, nilai t hitung sebesar 3,050 dan probabilitas tingkat signifikan sebesar 0,004 lebih kecil dari tingkat signifikan $(0,4 \%<a=0,05)$. Maka $\mathrm{H}_{3}=$ Firm Size berpengaruh terhadap Dividend Payout Ratio (DPR) diterima.

4. Variabel Debt to Equity Ratio (DER)

Nilai koefisien regresi variabel Debt to Equity Ratio (DER) yang diperoleh adalah sebesar -6,507, nilai $t$ hitung sebesar -1,368 dan probabilitas tingkat signifikansi sebesar 0,178 lebih besar dari tingkat signifikan $(17,8 \%>a=0,05)$. Maka $\mathrm{H}_{4}=$ Debt to Equity Ratio (DER) berpengaruh terhadap Dividend Payout Ratio (DPR) ditolak. 


\section{B. Pembahasan}

\section{Pengaruh ROA terhadap Dividend Payout Ratio}

Menurut (Harahap, 2010) ROA menggambarkan perputaran aktiva yang diukur dari penjualan. Semakin besar rasio ini maka semakin baik dan hal ini berarti aktiva dapat dimanfaatkan dengan optimal dan menghasilkan laba.Berdasarkan Signaling Theory atau teori sinyal yang dikemukakan oleh (Brigham \& Houston, 2011) bahwa isyarat atau sinyal adalah suatu tindakan yang diambil perusahaan untuk memberi petunjuk bagi investor tentang bagaimana manajemen memandang prospek perusahaan. ROA yang tinggi merupakan suatu sinyal yang menunjukkan bahwa perusahaan semakin efektif dalam memanfaatkan aktiva yang mana juga berdampak pada pembagian dividen. Hal inilah yang menarik minat para investor namuntidak sejalan dengan hasil penelitian yang menunjukkan bahwa ROA tidak berpengaruh terhadap DPR.

Hasil penelitian variabel Return On Assets (ROA) secara parsial tidak berpengaruh terhadap DPR karena probabilitas tingkat signifikan sebesar 0,528 lebih besar dari tingkat signifikan (52,8\% > a $=5 \%)$. ROA tidak selamanya mempengaruhi kebijakan dividen terutama pada perusahaan yang berada pada tahap maturity karena perusahaan-perusahaan tersebut telah mempunyai banyak cadangan laba yang dapat digunakan untuk diinvestasikan kembali ataupun juga untuk dibagikan kembali tanpa harus mengubah proporsi dividen bagi pemegang saham. Namun sejatinya, pembagian dividen dilakukan sesuai dengan hasil keputusan rapat umum pemegang saham yaitu apakah laba akan ditahan untuk diinvestasikan kembali atau akan dibagikan kepada para pemegang saham sebagai dividen. Maka,artinya ROA yang tinggi tidak dapat dijadikan acuan dalam pembagian dividen yang tinggi pula.

\section{Pengaruh CR terhadap Dividend Payout Ratio}

Current ratio (CR) merupakan rasio untuk mengukur kemampuan perusahaan dalam membayar kewajiban jangka pendek atau utang yang segera jatuh tempo pada saat ditagih secara keseluruhan. Sesuai dengan Signaling Theory yang mana sinyal merupakan suatu isyarat dalam bentuk tindakan yang diambil perusahaan untuk memberikan petunjuk bagi investor maka semakin tinggi Current Ratio (CR) menunjukkan bahwa semakin tinggi kemampuan perusahaan dalam memenuhi kewajiban jangka pendeknya maka hal itu memberikan sinyal kepada para investor tentang kemampuan perusahaan untuk membayar dividen yang dijanjikan. Namun, hal ini tidak sejalan dengan hasil penelitian yang didapatkan yaitu bahwa CR tidak berpengaruh terhadap DPR. Hasil penelitian variabel CR secara parsial tidak berpengaruh terhadap DPR karena data probabilitas tingkat signifikan sebesar 0,749 lebih 
besar dari tingkat signifikan $(74,9 \%>a=5 \%)$. CR tidak berpengaruh terhadap DPR dikarenakan likuiditas tidak hanya digunakan untuk membayar dividen melainkan dialokasikan pada pembelian aktiva tetap atau aktiva lancar yang permanen untuk memanfaatkan kesempatan investasi yang ada serta digunakan untuk biaya operasional.

\section{Pengaruh Firm Size terhadap Dividend Payout Ratio}

Firm Size (ukuran perusahaan) sebagai aspek dasar sangat dicermati dalam keputusan melakukan investasi. Semakin besar perusahaan maka semakin mudah akses informasinya. Ukuran perusahaan dapat dilihat berdasarkan total aset. Sesuai dengan Signaling Theory yang mana sinyal merupakan suatu isyarat dalam bentuk tindakan yang diambil perusahaan untuk memberikan petunjuk bagi investor maka perusahaan dengan ukuran yang lebih besar diperkirakan memiliki kemampuan untuk menghasilkan earning yang lebih besar sehingga dapat membayar dividen yang besar sebaliknya dengan perusahaan kecil. Berdasarkan hasil penelitian diperoleh data koefisien regresi Firm Size sebesar 4,161 dan probabilitas tingkat signifikan 0,004 lebih kecil dari tingkat signifikan $(0,4 \%<a=5 \%)$ yang menyatakan bahwa Firm Size berpengaruh signifikan terhadap DPR.

\section{Pengaruh DER terhadap Dividend Payout Ratio}

Debt to Equity Ratio (DER) merupakan rasio yang menggambarkan perbandingan utang dan ekuitas dalam pendanaan perusahaan dan menunjukkan kemampuan modal sendiri perusahaan tersebut untuk memenuhi seluruh kewajibannya (Ulfa, 2016). Menurut Pecking Order Theory, perusahaan cenderung akan lebih dahulu menggunakan pendanaan dari sumber internal sebelum memutuskan menggunakan dana eksternal. Penggunaan pendanaan eksternal ini akan meningkatkan rasio utang perusahaan. Semakin tinggi rasio utang sebuah perusahaan akan meningkatkan beban perusahaan juga risiko kebangkrutan. Hal ini akan memaksa pihak manajemen memutuskan kebijakan dividennya karena penurunan penerimaan laba bersih juga akan menurunkan rasio pembayaran dividen.

Namun hal ini tidak sejalan dengan hasil penelitian yaitu didapatkan data nilai koefisien regresi variabel Debt to Equity Ratio (DER) sebesar -6,507 dan probabilitas tingkat signifikansi sebesar 0,178 yang mana lebih besar dari tingkat signifikan $(17,8 \%>a=$ $0,05)$ yang menyatakan bahwa DER tidak berpengaruh terhadap DPR.Hal ini dikarenakan DER pada perusahaan sektor industri barang konsumsi yang menjadi sampel penelitian cenderung memiliki rasio yang stabil artinya perusahaan sektor industri 
barang konsumsi mengatur dan meminimalisir penggunaan dana dari luar dan mengendalikan utang dengan baik sehingga tetap konstan. Hal ini menunjukkan bahwa perusahaan sektor industri barang konsumsi mempunyai cukup dana dari laba ditahan, sehingga besaran rasio pembayaran dividen tidak terganggu oleh utang jangka panjang perusahaan.

\section{Hasil Analisis Berdasarkan Pengelompokkan Perusahaan}

Ringkasan hasil analisis korelasi pengelompokkan ini didapatkan dari data pengelompokkan melalui data total aset, kriteria korelasi dan hasil analisis regresi. Kelompok pertama memiliki korelasi cukup, searah dan tidak signifikan dengan hasil analisis regresinya berpengaruh antara DER dan DPR. Kelompok kedua memiliki korelasi kuat, berlawanan arah dan tidak signifikan dengan hasil analisis regresinya tidak berpengaruh antara CR dan DPR. Kelompok ketiga memiliki korelasi kuat, berlawanan arah dan signifikan dengan hasil analisis regresinya tidak berpengaruh antara CR dan DPR. Kelompok keempat memiliki korelasi kuat, berlawanan arah dan tidak signifikan dengan hasil regresinya tidak berpengaruh antara DER dan DPR.

\section{KESIMPULAN}

Penelitian ini meneliti pengaruh Return On Assets (ROA), Current Ratio (CR), Firm Size dan Debt to Equity Ratio (DER) terhadap Dividend Payout Ratio (DPR) pada perusahaan sektor industri barang konsumsi. Periode penelitan selama lima tahun yaitu pada tahun 2012 sampai dengan 2016. Sampel yang diambil berdasarkan beberapa kriteria adalah sebanyak 13 perusahaan. Berdasarkan hasil penelitian dan pembahasan yang telah dilakukan maka dapat diambil kesimpulan sebagai berikut:

1. Return On Assets (ROA) tidak berpengaruh terhadap Dividend Payout Ratio (DPR) pada perusahaan sektor industri barang konsumsi periode 2012-2016.

2. Current Ratio (CR) tidak berpengaruh terhadap Dividend Payout Ratio (DPR) pada perusahaan sektor industri barang konsumsi periode 20122016.

3. Firm Size berpengaruh positif dan signifikan terhadap Dividend Payout Ratio (DPR) pada perusahaan sektor industri barang konsumsi periode 2012-2016.

4. Debt to Equity Ratio (DER) tidak berpengaruh terhadap Dividend Payout Ratio (DPR) pada perusahaan industri barang konsumsi periode 20122016.

5. Hasil analisis hubungan dan regresi antar variabel melalui pengelompokkan data berdasarkan total aset perusahaan menyatakan bahwa pada kelompok pertama, DER mempunyai korelasi yang cukup, searah dan tidak signifikan terhadap DPR. Hasil regresi kelompok 
pertama menunjukkan hasil yang berpengaruh. Kelompok kedua, CR mempunyai korelasi yang kuat, berlawanan arah dan tidak signifikan. Hasil regresi kelompok kedua menunjukkan hasil yang tidak berpengaruh. Kelompok ketiga, CR mempunyai korelasi yang kuat, berlawanan arah dan tidak signifikan. Hasil regresi kelompok ketiga menunjukkan hasil yang tidak berpengaruh. Kelompok keempat, DER mempunyai korelasi kuat, berlawanan arah, tidak signifikan. Hasil regresi kelompok keempat menunjukkan hasil tidak berpengaruh.

\section{SARAN}

Berdasarkan kesimpulan yang telah dijelaskan, terdapat beberapa saran dalam penelitian ini yang mungkin dapat berguna baik bagi praktisi dan bagi peneliti selanjutnya. Adapun saran tersebut adalah sebagai berikut:

1. Bagi peneliti selanjutnya, sebaiknya bila ingin meneliti mengenai Dividend Payout Ratio (DPR) sebagai variabel dependen ada baiknya untuk menambahkan variabel independen selain Return On Assets (ROA), Current Ratio (CR), Firm Size dan Debt to Equity Ratio (DER) yang tidak digunakan dalam penelitian ini.

2. Bagi investor sebaiknya memperhatikan kondisi kinerja keuangan perusahaan, tidak hanya dengan melihat jumlah utang perusahaan namun juga melihat keseluruhan performansi keuangan perusahaan. Mudahnya akses yang didapatkan perusahaan besar dalam memperoleh dana melalui pasar modal juga dapat dipertimbangkan karena hal tersebut berdampak pada besarnya dividen yang dibayarkan perusahaan di masa mendatang.

3. Return On Assets (ROA), Current Ratio (CR) dan Debt to Equity Ratio (DER) yang tidak berpengaruh dari hasil penelitian ini sebaiknya jangan diabaikan karena besarnya laba serta utang perlu dikontrol agar tidak menimbulkan masalah di kemudian hari yang dapat membuat perusahaan berada pada keadaan yang sulit.

\section{UCAPAN TERIMAKASIH}

Ucapan terima kasih penulis sampaikan kepada seluruh narasumber yang bersedia membantu dan memberikan informasi yang diperlukan pada penelitian ini. Ucapan terima kasih juga kami sampaikan kepada para pihak yang membantu dalam selesainya tulisan ini. 


\section{REFERENSI}

Afrina, T. (2014). Pengaruh Current Ratio, DER, dan ROA terhadap DPR Perusahaan Rokok di BEI. Jurnal Ilmu Dan Riset Manajemen, 3(9), 1375-1386.

Ano, R. R., Murni, S., \& Van Rate, P. (2014). Pengaruh Likuiditas Dan Profitabilitas Terhadap Devidend Payout Ratio Pada Subsektor Perbankan Yang Terdaftar Di Bursa Efek Indonesia Periode 2009-2013. Jurnal EMBA: Jurnal Riset Ekonomi, Manajemen, Bisnis Dan Akuntansi, 2(3).

Astiti, N. K. A., Yuniarta, G. A., AK, S. E., \& Edy Sujana, S. E. (2017). Pengaruh Debt To Equity Ratio (Der), Current Ratio (Cr), Net Present Margin (Npm), Return On Asset (Roa), Terhadap Dividend Payout Ratio (Dpr) Studi Pada Perusahaan Basic Industry Dan Properti, Real Estate \& Building Contruction Yang Terdaftar Di Bursa Efek Indonesia Periode 2011-2015. JIMAT (Jurnal Ilmiah Mahasiswa Akuntansi) Undiksha, 7(1).

Brigham, E. F., \& Houston, J. F. (2011). Dasar-Dasar Manajemen Keuangan, Edisi Kesebelas. Jakarta: Salemba Empat.

Deni, F. F., Aisjah, S., \& Djazuli, A. (2016). Analisis variabel-variabel yang mempengaruhi kebijakan dividen (Studi pada perusahaan manufaktur yang terdaftar di Bursa Efek Indonesia). Jurnal Aplikasi Manajemen, 14(2), 359-365.

Ghozali. (2011). Aplikasi Analisis Multivariate dengan Program IBM SPSS 19, Semarang: Badan Penerbit Universitas Diponegoro. Gibson. 2001. Organisasi Perilaku-Struktur-Proses, Terjemahan Agus Dharma. Edisi 5. Jakarta: Penerbit Erlangga Haryanto, Danny. 2014. E-Jurnal Manajemen Universitas Udayana, 5, 9.

Gumanti, T. A. (2013). Kebijakan Dividen Teori, Empiris dan Implikasi.

Hanif, M., \& Bustamam, B. (2017). Pengaruh Debt To Equity Ratio, Return On Asset, Firm Size, dan Earning Pe Share terhadap Dividend Payout Ratio (Studi pada Perusahaan Manufaktur yang Terdaftar di Bursa Efek Indonesia Tahun 2011-2015). Jurnal Ilmiah Mahasiswa Ekonomi Akuntansi, 2(1), 73-81.

Harahap, S. S. (2010). Analisis Kritis Atas Laporan Keuangan. Rajawali Persada.

Janifairus, J. B., Hidayat, R., \& Husaini, A. (2013). Pengaruh return on asset, debt to equity ratio, assets growth, dan cash ratio terhadap dividend payout ratio. Jurnal Administrasi Bisnis (JAB)| Vol, 1(1).

Kartika, A. V. (2015). Pengaruh Return On Assets, Return On Equity dan Assets Growth Terhadap Dividend Payout Ratio (Studi Pada Perusahaan Manufaktur Yang Terdaftar di Bursa Efek Indonesia Periode 2010-2012). Brawijaya University.

Lioew, A. M., Murni, S., \& Mandagie, Y. (2014). ROA, ROE, NPM Pengaruhnya 
Terhadap Dividen Payout Ratio Pada Perusahaan Perbankan Dan Financial Institusi Yang Terdaftar Di Bei Periode 2010-2012. Jurnal EMBA: Jurnal Riset Ekonomi, Manajemen, Bisnis Dan Akuntansi, 2(2).

Marietta, U. \& D. S. (2013). Analisis Pengaruh Cash Ratio, Return On Assets, Growth, Firm Size, Debt to Equity Ratio Terhadap Dividend Payout Ratio: (Studi Pada Perusahaan Manufaktur Yang Terdaftar di Bursa Efek Indonesia Tahun 2008-2011. Diponegoro Journal of Accounting, 2(3).

Pribadi, A. S. \&R. D. S. (2012). Analisis Pengaruh Cash Position, Firm Size, Growth Opportunity, Ownership dan Return On Asset Terhadap Dividend Payout Ratio. Diponegoro Journal of Management, 1(1), 212-211.

Ritha, H., \& Koestiyanto, E. (2013). Faktor-Faktor yang Mempengaruhi Dividend Payout Ratio (DPR).

Sanusi, A. (2016). Metodologi Penelitian Bisnis. Salemba empat.

Silviana, C. (2014). Analisis Variabel-Variabel Yang Mempengaruhi Kebijakan Dividen (Studi pada Saham Indeks LQ-45 di BEI Periode 2010-2012). Brawijaya University.

Sudana, I. M. (2011). Manajemen Keuangan Perusahaan Teori dan Praktik. Erlangga.

Swastyastu, M. W., Yuniarta, G. A., AK, S. E., Atmadja, A. T., \& SE, A. (2014). Analisis faktor-faktor yang mempengaruhi kebijakan dividend payout ratio yang terdaftar di Bursa Efek Indonesia (BEI). JIMAT (Jurnal Ilmiah Mahasiswa Akuntansi) Undiksha, 2(1).

Ulfa, L. M. dan T. Y. (2016). Pengaruh Kinerja Keuangan, Asset Growth dan Firm Size Terhadap Dividend Payout Ratio. Jurnal Ilmu Dan Riset Manajemen, 5, 116.

Usman, H., \& Mustafa, S. W. (2016). Pengaruh CR, DER dan ROA Terhadap Dividend Payout Ratio Pada Beberapa Perusahaan Pertambangan yang Terdaftar di BEI (2011-2013). Jurnal Akuntansi STIE Muhammadiyah Palopo, $1(2)$. 